\title{
Actual status of veralipride use
}

\author{
This article was published in the following Dove Press journal: \\ Clinical Interventions in Aging \\ 3I August 2010 \\ Number of times this article has been viewed
}

\section{Sebastián Carranza-Lira \\ Reproductive Medicine Service. Hospital de Ginecología y Obstetricia "Luis Castelazo Ayala" Instituto Mexicano del Seguro Social, México DF}

Correspondence: Sebastián Carranza-Lira Puente de piedra I50-422 Torre I. Col. Toriello Guerra, CP I4050, México DF Email scarranzal@mexis.com

\begin{abstract}
During the climacteric period, several symptoms exist that motivate women to seek medical advice; one of the most common is the hot flush, which presents in $75 \%-85 \%$ of these during a variable time span. For the treatment of hot flush, several non-hormonal treatments exist; among them, veralipride has shown to be a useful treatment of vasomotor symptoms during the climacteric period. In recent times, several medical societies have discredited its use. The purpose of this review, therefore, is to define a measured position in relation to the use of this drug. On completion of this review, it was possible to conclude that this drug has an antidopaminergic mechanism of action. The recommended schedule is: $100 \mathrm{mg} /$ day for 20 days, with 10 days drug free. Since the risk of undesirable secondary effects such as galactorrhea, mastodynia, and extrapyramidal can increase with use, no more than 3 treatment cycles are recommended. This drug has a residual effect that can allow drug-free intervals, which permit a longer time between schedules.
\end{abstract}

Keywords: veralipride, hot flushes, climacteric, menopause, symptoms, secondary effects

\section{Introduction}

During the climacteric period, several symptoms exist that motivate women to seek medical advice. One of the most frequent is the hot flush, which presents in $75 \%-85 \%$ of these for a variable time span.

The hot flush is defined as a sudden hot sensation in the face, neck, and chest, which can have different intensity and frequency during the day and night and can be accompanied by sweating, flushing, throbs, anxiety, or irritability. ${ }^{1}$ The hot flush has an average duration of 4 minutes but can last from a few seconds to 10 minutes. ${ }^{2}$

For hot flushes to occur, estradiol serum levels need to have decreased. This produces changes in hypothalamic neurotransmitters such as those synthesized in noradrenergic and dopaminergic neurons. The increase in noradrenergic tone modifies the opioid system and in concert with the decrease in dopaminergic tone modifies the release of gonadotrophin-releasing hormone $(\mathrm{GnRH})$ and luteinizing hormone $(\mathrm{LH}){ }^{3}$ which traduce an increase in its pulsatility. These neurotransmitters by themselves promote instability of the thermoregulatory center and condition vasomotor symptoms. ${ }^{4}$ Also, it has been observed that estrogen deficiency is associated with a decrease in serotonin levels allowing hot flushes to occur, probably due to an interconnection between this neurotransmitter and noradrenaline. ${ }^{5}$

For the treatment of climacteric symptoms, several drugs have been used with different results in relation to their effectiveness and secondary effects. ${ }^{6}$ The most representative studies with these drugs are shown in Table 1. 
Table I Hot flushes decrease with several treatments

\begin{tabular}{|c|c|c|c|c|c|}
\hline & Mechanism & Dose & $\begin{array}{l}\text { Hot flushes } \\
\text { decrease vs placebo }\end{array}$ & Secondary effects & Withdrawal (\%) \\
\hline Clonidine & $\alpha-2$ adrenergic & & & & - \\
\hline Carranza-Lira $^{7}$ & agonist & $0.1 \mathrm{mg} \mathrm{e} / \mathrm{I} 2 \mathrm{hr}$ & $83 \%$ vs $50 \%$ & $\begin{array}{l}\text { Mouth dryness, } \\
\text { depression, nauseas, } \\
\text { insomnia, somnolence }\end{array}$ & \\
\hline Gabapentin & GABA analog & & & & - \\
\hline Reddy $^{8}$ & & $900 \mathrm{mg} /$ day & $54 \%-71 \%$ vs 29 & $\begin{array}{l}\text { Dizziness, headache, } \\
\text { disorientation up to } 50 \%\end{array}$ & \\
\hline Biglia ${ }^{9}$ & & $900 \mathrm{mg} /$ day & $\begin{array}{l}\text { Frequency } 57.0 \% \\
\text { Intensity } 66.9 \%\end{array}$ & & 34.8 \\
\hline Venlafaxine & SNRI & & & & - \\
\hline Evans $^{10}$ & & 75 mg/day & $61 \%$ vs $20 \%$ & Anti-cholinergic effects & - \\
\hline Phillips"I & & $75-225 \mathrm{mg} /$ day & & Hepatitis & - \\
\hline Ladd $^{12}$ & & & $60 \%$ & & \\
\hline Desvenlafaxine & SNRI & & & & \\
\hline Archer 13,14 & & $100-150$ mg/day & $\begin{array}{l}63 \% \text { vs } 47 \% \\
66.6 \% \text { vs } 50.8 \%\end{array}$ & & More than placebo \\
\hline Speroff ${ }^{15}$ & & $100 \mathrm{mg} /$ day & $64 \%$ & & - \\
\hline \multicolumn{6}{|l|}{ Paroxetine } \\
\hline Stearns ${ }^{16}$ & SSRI & $25 \mathrm{mg} /$ day & $65 \%$ vs $38 \%$ & & - \\
\hline Fluoxetine & SSRI & & & & \\
\hline Loprinzi $^{17}$ & & $20 \mathrm{mg} /$ day & $50 \%$ vs $36 \%$ & & - \\
\hline Oktem $^{18}$ & & $20 \mathrm{mg} /$ day & $62 \%$ & & 33 \\
\hline Suvanto-Luukonen 19 & & $10-30 \mathrm{mg} /$ day & No better than placebo & & 34 \\
\hline Citalopram & SSRI & & & & \\
\hline Suvanto-Luukonen ${ }^{19}$ & & $10-30 \mathrm{mg} / \mathrm{day}$ & No better than placebo & & 34 \\
\hline Soares ${ }^{20}$ & & $20-60 \mathrm{mg} /$ day & $86.6 \%$ decrease in depression & & - \\
\hline Kalay ${ }^{21}$ & & $10-20 \mathrm{mg} /$ day & $37 \%$ vs $13 \%$ & & - \\
\hline Propranolol & $\beta$ adrenergic & & & & \\
\hline Carranza $^{7}$ & blocker & $20 \mathrm{mg} \mathrm{e} / \mathrm{I} 2 \mathrm{hr}$ & $50 \%$ vs $50 \%$ & & - \\
\hline Coope $^{22}$ & & $40 \mathrm{mg}$ e/8 hr & Similar than placebo & & - \\
\hline Alcoff $^{23}$ & & & Favorable vs placebo & & - \\
\hline \multicolumn{6}{|l|}{ Vitamin E } \\
\hline Barton $^{24}$ & & $800 \mathrm{IU} /$ day & $\begin{array}{l}\text { One hot flush less than } \\
\text { with placebo }\end{array}$ & $\begin{array}{l}\text { Clinically similar to } \\
\text { placebo }\end{array}$ & - \\
\hline \multirow[t]{2}{*}{ Biglia $^{25}$} & & & Frequency $10.2 \%$ & & \\
\hline & & & Intensity $7.28 \%$ & & 34.8 \\
\hline Methyil-dopa & $\alpha 2$ adrenergic & & & & \\
\hline Andersen ${ }^{26}$ & agonist & $375-1125 \mathrm{mg} /$ day & $65 \%$ vs $38 \%$ & & - \\
\hline Nesheim ${ }^{27}$ & & $250-500 \mathrm{e} / \mathrm{I} 2 \mathrm{hr}$ & $85 \%$ & & 33 \\
\hline \multicolumn{6}{|l|}{ Cimicifuga } \\
\hline Oktem ${ }^{18}$ & & $40 \mathrm{mg} / \mathrm{day}$ & $85 \%$ & & 33 \\
\hline Jacobson ${ }^{28}$ & & Not indicated & No better than placebo & & Risk of hepatotoxycity ${ }^{30}$ \\
\hline Borrelli ${ }^{29}$ & & $4 \mathrm{mg} \mathrm{e} / \mathrm{I} 2 \mathrm{hr}$ & Similar to estrogen & & - \\
\hline
\end{tabular}

Abbreviaitons: SSRI, serotonin selective reuptake inhibitors; SNRI, serotonin noradrenalin reuptake inhibitors.

Veralipride is another drug that has shown its effectiveness, and it has been considered a good therapeutic alternative for climacteric-related vasomotor symptoms when a contraindication or non-acceptance of hormone therapy (HT) exists. Veralipride can also be used in association with other drugs that do not confer any control of vasomotor symptoms; for example, raloxifene, whose main indication is for postmenopausal women with risk of or established osteopenia-osteoporosis. ${ }^{31}$
Veralipride has been used for a long time. Recent studies have proved its efficiency in the recommended dose of $100 \mathrm{mg} /$ day ${ }^{32}$ however, at this time some medical societies ${ }^{33}$ and government organizations ${ }^{34}$ have discredited its use due to its secondary adverse effects. The still in use Mexican Official Norm for the prevention and control of perimenopausal and postmenopausal diseases in women establishes that the drug can be useful in the control of vasomotor symptoms. ${ }^{35}$ 
For all previously exposed the purpose of this work is to review the current evidence with veralipride and define a measured position without bias in relation to its use.

\section{Pharmacology}

Veralipride is a dopaminergic antagonist of receptor D2, whose formula is N-[allyl-1 pyrrolidinyl-2) methyl] dimethoxy-2,3sulfamoyl-5 benzamide. ${ }^{36}$ This drug induces prolactin secretion without any estrogenic or progestagenic effects. Serum levels of follicle stimulating hormone, LH, estradiol, and estrone aren't modified ${ }^{37}$ However, some studies have reported that $\mathrm{LH}$ can decrease. Prolactin increase and LH decrease can be explained by a stimulation of endogenous opioid activity. ${ }^{3,38}$ This drug is well absorbed when administered orally, achieving maximal concentrations at 2.5 hours. It is poorly metabolized and is eliminated in the urine and feces. After oral administration, the half-life is 4 hours, and $44 \%$ is excreted without any changes in urine in the first 120 hours. ${ }^{3}$

\section{Clinical studies}

When evaluating hot flushes, frequency and intensity are taken in account. With veralipride, it has been reported that since the 4th treatment day, hot flushes begin to subside. ${ }^{3}$ In other studies in which veralipride has been compared against placebo, it has been reported that there is a statistically significant reduction in frequency as well as in intensity of hot flushes after 20 days of continuous treatment at a dose of $100 \mathrm{mg} /$ day. $^{3}$

When comparing veralipride with HT, a decrease in frequency of hot flushes of $80 \%$ versus $100 \%$ and of intensity of $71 \%$ versus $100 \%$, respectively, has been observed. ${ }^{7}$
Most of the studies agree that the decrease of hot flushes with veralipride use is from $48.0 \%$ to $89.9 \%$ depending on time of use and method of administration.

Several ways of prescribing veralipride have been reported and not always in accordance with the product directions - many times due to ignorance and others with the idea of decreasing the secondary effects such as hyperprolactinemia as well as those extrapyramidal.

The schedules in use have different rates of effectiveness (Table 2) and secondary effects and are: ${ }^{7,36,39-41}$

a. Classic schedule, $100 \mathrm{mg}$ /day for 20 days, with 10 days drug free for no more than 6 months;

b. $100 \mathrm{mg} /$ day for 7 days, followed by $100 \mathrm{mg}$ every 48 hours for 1 month, followed by $100 \mathrm{mg}$ /day twice a week for 3-6 months;

c. $100 \mathrm{mg} /$ day from Monday to Friday with Saturday and Sunday free of treatment;

d. $100 \mathrm{mg} /$ day for 2 days, and 2 days without treatment, and then repeat;

e. $100 \mathrm{mg}$ every 48 hours for 3-6 months.

Leo et al indicate that every veralipride prescription schedule must be individualized, and that 6 cycles of treatment are not associated with addiction. ${ }^{3}$

\section{Secondary effects}

One of the main secondary effects of veralipride use is hyperprolactinemia, which may or may not be accompanied by galactorrhea, and can disappear at 48 hours of treatment

Table 2 Veralipride efficiency with several evaluated schedules

\begin{tabular}{|c|c|c|c|c|c|}
\hline & Schedule & $\mathbf{N}$ & Time & Study & Results \\
\hline David ${ }^{36}$ & A & 47 & 2 months & $\begin{array}{l}\text { Double blind, placebo controlled, } \\
\text { crossover }\end{array}$ & $\begin{array}{l}\text { Hot flush reduction } 80 \% \\
\text { Residual effect } 3 \text { months after withdrawal }\end{array}$ \\
\hline Wesel $^{39}$ & B & 40 & & Double blind, randomized & Similar decrease in hot flushes between groups \\
\hline Melis ${ }^{40}$ & $\mathrm{C}$ & 40 & I month & $\begin{array}{l}\text { Randomized, double blind, } \\
\text { placebo controlled }\end{array}$ & $85 \%$ reduction \\
\hline Vercellini $^{4 I}$ & $\mathrm{D}$ & 36 & 2 months & $\begin{array}{l}\text { Randomized, double blind, } \\
\text { placebo controlled }\end{array}$ & Reduction $78 \%$ vs placebo $33 \%$ \\
\hline Carranza-Lira ${ }^{7}$ & $E$ & 75 & 3 months & $\begin{array}{l}\text { Comparative, randomized, } \\
\text { placebo controlled }\end{array}$ & $\begin{array}{l}80 \% \text { reduction in frequency, } 71 \% \text { in intensity, } 82 \% \\
\text { duration, sweats } 66.6 \%\end{array}$ \\
\hline Morgante ${ }^{31}$ & $\mathrm{~F}$ & 29 & 6 months & Randomized, comparative & $\begin{array}{l}\text { Without differences between in number of hot } \\
\text { flushes and Kupperman's index } \\
\text { Hot flushes decrease in } 63 \% \text { and } 66 \% \text { at } 3 \text { rd and } \\
6 \text { th month respectively }\end{array}$ \\
\hline Boukobza $^{42}$ & G & 166 & 3 months & Open, multicentric & $\begin{array}{l}\text { Hot flush reduction } 89.9 \% \\
\text { In } 64.5 \% \text { residual effect } 3 \text { months after withdrawal }\end{array}$ \\
\hline Vercellini $^{43}$ & $\mathrm{H}$ & 25 & 28 days & Open, observational trial & $\begin{array}{l}92 \% \text { of patients have decrease in frequency and } \\
\text { intensity of hot flushes }\end{array}$ \\
\hline Marais ${ }^{44}$ & I & - & I-I4 months & Comparative, placebo controlled & $48 \%-72 \%$ decrease \\
\hline
\end{tabular}

Notes: A, $100 \mathrm{mg} /$ day for 20 days and 10 days drug free; B, $100 \mathrm{mg} /$ day for 20 days and 10 days drug free versus conjugated estrogens $1.25 \mathrm{mg} /$ day; , $100 \mathrm{mg} /$ day; $\mathrm{D}, 100 \mathrm{mg} /$ day; E, $100 \mathrm{mg} /$ day from Monday to Friday; F, Raloxifene plus veralipride in alternate days versus raloxifene and veralipride in alternate months; G, $100 \mathrm{mg} /$ day for 20 days and 10 days drug free; $\mathrm{H}, 100 \mathrm{mg} /$ day 20 days. 
withdrawal, ${ }^{39}$ other studies indicate that the normalization of prolactin levels can take 2 or 3 weeks. ${ }^{45}$ Reported prolactin levels after 2 cycles have been $106.2 \pm 41.5 \mathrm{ng} / \mathrm{mL} ;{ }^{39}$ others have reported levels 10 times higher than those at baseline. ${ }^{46}$ A clinical study reported that after veralipride administration at a dose of $100 \mathrm{mg}$ /day for 6 months on alternate days or months, the prolactin levels were not higher than $21 \mathrm{ng} / \mathrm{mL} .^{7}$ Other reported secondary effects have been galactorrhea, headache, nervousness, insomnia, depression, mastodynia, and weight increase.

The most serious effects that have been reported with veralipride use are those extrapyramidal, such as acute dyskinesia, tardive dyskinesia, Parkinsonism, postural tremor, myoclonia, and dystonia. Many of these have been related to over-dosage and due to the lack of prescription instruction follow-up; however, this it is not always the case. ${ }^{10,42,46,47}$ See Table 3 .

It's worth mentioning that the Pharmacovigilance committee from the laboratory that produces this drug in Mexico has reported that sales in 5 years have been $2,265,729$ pieces. In this time they have been informed of only 35 adverse effects. Of these, 21 have been attributed to incorrect medication use: anxiety (6), depression (6), abnormal movements (2), weight gain (2), lower limb pain (2), neck rigidity (1), galactorrhea (1), and muscular weakness (1). Those which presented after adequate drug intake numbered 14: insomnia (3), nervousness (2), fear (2), fine tremor (1), irritability (1), lack of appetite (1), mastitis (1), galactorrhea (1), pain (1), and head pain (1). ${ }^{52}$

\section{Contraindications and prescription recommendations}

After the review of several non-hormonal options for the treatment of climacteric hot flushes it can be concluded that for a drug to be considered as a good option for the treatment of vasomotor symptoms, an evaluation of the risk-benefit of the chosen therapy is always needed, and this must be well supported by clinical studies that evaluate safety parameters. ${ }^{53}$

Those women than can be candidates for veralipride use must achieve an adequate clinical profile, which means they will lack any history of tardive dyskinesia, Parkinsonism, acute dyskinesia, postural tremor, myoclonia, dystonia, hyperprolactinemia, breast fibrocystic disease, depression, and breast cancer. ${ }^{37}$

\section{Conclusion}

After this review it can be concluded that veralipride is a good option, and a safe drug if recommended doses are
Table 3 Secondary effects with veralipride use, according to schedule

\begin{tabular}{|c|c|c|c|}
\hline & Secondary effect & Schedule & $\mathbf{N}$ or $\%$ \\
\hline David $^{36}$ & Depression+ & $\begin{array}{l}100 \mathrm{mg} / \text { day } 20 \text { days } \\
\text { and } 10 \text { days drug free }\end{array}$ & $19 \%-47 \%$ \\
\hline \multirow[t]{7}{*}{ Boukozoba $^{42}$} & Breast tenderness & 100 mg/day 20 days & $1.2 \%$ \\
\hline & Insomnia & and 10 days drug & $0.6 \%$ \\
\hline & Mouth dryness & free for 3 months & $0.6 \%$ \\
\hline & Somnolence & & $1.2 \%$ \\
\hline & Digestive problems & & $0.6 \%$ \\
\hline & Dizziness & & $0.6 \%$ \\
\hline & Weakness & & $0.6 \%$ \\
\hline \multirow[t]{8}{*}{ Masmoudi ${ }^{46}$} & Parkinsonism & Several schedules & $\mathrm{N}$ \\
\hline & Acute dyskinesia & & 15 \\
\hline & Parkinsonism plus & & 2 \\
\hline & other in 8 cases & & \\
\hline & Tardive dyskinesia & & 6 \\
\hline & Postural tremor & & 3 \\
\hline & Myoclonia & & I \\
\hline & Dystonia & & I \\
\hline Montemurro ${ }^{47}$ & $\begin{array}{l}\text { Acute coronary } \\
\text { syndrome }\end{array}$ & $100 \mathrm{mg} /$ day & I \\
\hline \multirow[t]{6}{*}{ Kunhardt ${ }^{48}$} & Pyrosis & 100 mg/day 20 days & I \\
\hline & Hair fall & and 10 days drug free & I \\
\hline & Mamary pruritus & & I \\
\hline & Mastodynia & & 3 \\
\hline & Placebo & & \\
\hline & $\begin{array}{l}\text { Headache, joint } \\
\text { pain, vaginal } \\
\text { discharge } \\
\text { mastodynia } \mathrm{I} / \mathrm{e}\end{array}$ & & I each \\
\hline Raja $^{49}$ & Tardive dyskinesia & Not reported & I \\
\hline Sining ${ }^{50}$ & $\begin{array}{l}\text { Dystonia } \\
\text { (Hypertension } \\
\text { under enalapril } \\
\text { treatment) }\end{array}$ & $\begin{array}{l}100 \text { mg/day } \\
\text { (2 months) }\end{array}$ & I \\
\hline Teive $^{51}$ & $\begin{array}{l}\text { Increase in } \\
\text { Parkinsonian } \\
\text { symptoms }\end{array}$ & Not reported & I \\
\hline
\end{tabular}

respected. ${ }^{3}$ Its high effectiveness in the control of vasomotor symptoms allows a high number of patients to be benefited.

The presentation of secondary adverse events is decreased using this medicament at a dose no greater than $100 \mathrm{mg} /$ day, for short time spans, and leaving drug-free intervals between schedules. The drug-free intervals will not decrease drug favorable effects due to the drug's residual effect as shown before.

It's worth investigating safety aspects in the LatinAmerican population as well as the use of low-dose. Recently, the Mexican Association for the Study of the Climacteric, gave the following recommendations when veralipride is prescribed. 
1. An evaluation of medical history must be carried out, following a strict selection profile according to medical history, particularly of neuropsychiatric problems. ${ }^{37,46}$

2. Respect the schedule and dose indicated by producer ( 20 treatment days with 10 days drug free)..$^{37,46,53}$

3. Don't give more than 3 treatment cycles together, and don't repeat more than twice in a year (no more than 6 cycles per year). ${ }^{3}$

4. In those women with chronic use, the drug must be gradually withdrawn to avoid withdrawal symptoms..$^{3,38,53}$

\section{Disclosure}

The author reports no conflicts of interest in this work.

\section{References}

1. Hickey M, Saunders CM, Stuckey BGA. Non-hormonal treatments for menopausal symptoms. Maturitas. 2007;57:85-89.

2. Kronenberg F. Hot flashes: epidemiology and physiology. Ann NY Acad Sci. 1990;592:52-86.

3. de Leo V, Morgante G, Musacchio MC, Faldini E, Delia A, Petraglia F. The safety of veralipride. Expert Opin Drug Saf. 2006;5: 695-701.

4. Lobo R. Menopause and aging. In: Strauss JF, Barbieri RL, editors. Yen and Jaffe's Reproductive Endocrinology. Physiology, Pathophysiology and Clinical Management. 6th ed. Philadelphia: Saunders Elsevier; 2009:325-355.

5. Berendsen HH. The role of serotonin in hot flushes. Maturitas. 2000;36: 155-164.

6. Nelson HD, Vesco KK, Haney E, et al. Non-hormonal therapies for menopausal hot flashes. JAMA. 2006;295:2057-2071.

7. Carranza-Lira S, Cortés-Fuentes E. Modification of vasomotor symptoms after various treatment modalities in the postmenopause. Int $J$ Gynecol Obstet. 2001;23:169-171.

8. Reddy SY, Warner H, Guttuso T, et al. Gabapentin, estrogen, and placebo for treating hot flushes: a randomized controlled trial. Obstet Gynecol. 2006;108:41-48.

9. Biglia N, Sgandurra P, Peano P, et al. Non-hormonal treatment of hot flushes in breast cáncer survivors: gabapentin vs vitamin E. Climacteric. 2009;12:310-318.

10. Evans ML, Pritts E, Vittinghoff E, et al. management of postmenopausal hot flushes with venlafaxine hydrochloride: a randomized, controlled trial. Obstet Gynecol. 2005;105:161-166.

11. Phillips BB, Digmann RR, Beck MG. Hepatitis associated with low-dose venlafaxine for postmenopausal vasomotor symptoms. Ann Pharmacother. 2006;40:323-327.

12. Ladd CO, Newport DJ, Ragan KA, Loughhead A, Stowe ZN. Venlafaxine in the treatment of depressive and vasomotor symptoms in women with perimenopausal depression. Depress Anxiety. 2005;22:94-97.

13. Archer DF, Dupont CM, Constantine GD, Pickar JH, Olivier S. Desvenlafaxine for the treatment of vasomotor symptoms associated with menopause: a double-blind, randomized, placebo-controlled trial of efficacy and safety. Am J Obstet Gynecol. 2009;200: 238.e1-238.e10.

14. Archer DF, Seidman L, Constantine GD, Pickar JH, Olivier S. A doubleblind, randomly assigned, placebo-controlled study of desvenlafaxine efficacy and safety for the treatment of vasomotor symptoms associated with menopause. Am J Obstet Gynecol. 2009;200:172.e1-172.e10.

15. Speroff L, Gass M, Constantine G, Olivier S. Efficacy and tolerability of desvenlafaxine succinate treatment for menopausal vasomotor symptoms: a randomized controlled trial. Obstet Gynecol. 2008;111:77-87.
16. Stearns V, Beebe KL, Iyengar M, Dube E. Paroxetine controlled release in the treatment of menopausal hot flashes: a randomized controlled trial. JAMA. 2003;289:2827-2834.

17. Loprinzi CL, Sloan JA, Pérez EA, et al. Phase III evaluation of fluoxetine for treatment of hot flashes. J Clin Oncol. 2002;20:1578-1583.

18. Oktem M, Eroglu D, Karahan HB, Taskintuna N, Kuscu E, Zeyneloglu HB. Black cohosh and fluoxetine in the treatment of postmenopausal symptoms: a prospective, randomized trial. Adv Ther. 2007;24:448-461.

19. Suvanto-Luukkonen E, Koivunen R, Sundstrom H, et al. Citalopram and fluoxetine in the treatment of postmenopausal symptoms: a prospective, randomized, 9-month, placebo-controlled, double-blind study. Menopause. 2005;12:18-26.

20. Soares CN, Poitras JR, Prouty J, Alexander AB, Shifren JL, Cohen LS. Efficacy of citalopram as a monotherapy or as an adjunctive treatment to estrogen therapy for perimenopausal and postmenopausal women with depression and vasomotor symptoms. J Clin Psychiatry. 2003;64: 473-479.

21. Kalay AE, Demir B, Haberal A, Kalay M, Kandemir O. Efficacy of citalopram on climacteric symptoms. Menopause. 2007;14: 223-229.

22. Coope J, Williams S, Patterson JS. A study of the effectiveness of propranolol in menopausal hot flushes. Br J Obstet Gynaecol. 1978;85: $472-475$.

23. Alcoff JM, Campbell D, Tribble D, Oldfield B, Cruess D. Doubleblind, placebo-controlled, crossover trial of propranolol as treatment for menopausal vasomotor symptoms. Clin Ther. 1981;3: 356-364.

24. Barton DL, Loprinzi CL, Quella SK, et al. Prospective evaluation of vitamin E for hot flashes in breast cancer patients. J Clin Oncol. 1998;16: 495-500.

25. Biglia N, Sgandurra P, Peano E, et al. Non-hormonal tratment of hot flushes in breast cancer survivors: gabapentin vs vitamin E. Climacteric. 2009:12:310-318.

26. Andersen O, Engebretsen T, Solberg VM, Orbo A. alpha-Methyldopa for climacteric hot flshes. A double-blind, randomized, cross-over study. Acta Obstet Gynecol Scand. 1986;65:405-409.

27. Nesheim BI, Saetre T. Reduction of menopausal hot flushes by methyldopa. A double blind crooser trial. Eur J Clin Pharmacol. 1981;20: 413-416.

28. Jacobson JS, Troxel AB, Evans J, et al. Randomized trial of black cohosh for the treatment of hot flashes among women with a history of breast cancer. J Clin Oncol. 2001;19:2739-2745.

29. Borrelli F, Ernzt E. Black cohosh (Cimicifuga racemosa) for menopausal symptoms: a systematic review of its efficacy. Pharmacol Res. 2008;58:8-14.

30. Lontos S, Jones RM, Angus PW, Gow PJ. Acute liver failure associated with the use of herbal preparations containing black cohosh. Med J Aust. 2003;179:390-391.

31. Morgante G, Farina M, Cianci A, La Marca A, Petraglia F, de Leo V. Veralipride administered with raloxifene decreases hot flushes and improve bone density in early postmenopausal women. Gynecol Endocrinol. 2004;18:194-198.

32. Carretti N, Florio P, Reis FM, Comai S, Bertazzo A, Petraglia F. Reduction of serum serotonin precursor after veralipride treatment for postmenopausal hot flushes. Climacteric. 2010;13:141-146.

33. European Medicines Agency. Doc Ref. EMEA/299873/2007.

34. World Health Organization. More risks tan benefits with veralipide; marketing authorization withdrawn for all medicinal products containing veralipride. QSM/MC/IEA 11.6. 2007 Jul 23.

35. Norma Oficial Mexicana NOM-035-SSA2-2002, Prevención y control de enfermedades en la perimenopausia y postmenopausia de la mujer. Criterios para brindar la atención médica.

36. David A, Don R, Tajchner G, Weissglas L. Veralipride: alternative antidopaminergic treatment for menopausal symptoms. Am J Obstet Gynecol. 1988;158:1107-1115.

37. Diccionario de especialidades farmacéuticas. 56 ed. México D.F. Thomson PLM S.A. de C.V., 2010:252-253. 
38. Melis GB, Gambacciani M, Cagnacci A, Paoletti AM, Mais V, Fioretti P. Effects of the dopamine antagonist veralipride on hot flushes and luteinizing hormone secretion in postmenopausal women. Obstet Gynecol. 1988;72:688-692.

39. Wesel S, Bourrguignon RP, Bosuma WB. Veralipride versus conjugated oestrogens: a double-blind study in the management of menopausal hot flushes. Curr Med Rev Opin. 1984;8:696-700.

40. Melis GB, Gambacciani M, Cagnacci A, Paoletti AM, Mais V, Fioretti P. Effects of dopamine antagonist veralipride on hot flushes and luteinizing hormone secretion in postmenopausal women. Obstet Gynecol. 1988; 72:688-692.

41. Vercellini P, Sacerdote P, Trespidi L, Manfredi B, Panerai AE, Crosignani PG. Veralipride for hot flushes induced by a gonadotropin-releasing hormone agonist: a controlled study. Fertil Steril. 1994;62:938-942.

42. Boukobza G. Efficacité et tolerance du veralipride dans le traitement des bouffes de chaleur de la menopause. Étude multicentrique. Rev Fr Gynecol Obstet. 1986;8:413-417.

43. Vercellini P, Vendola N, Colombo A, Passadore C, Trespidi L, Crosigniani PG. Veralipride for hot flushes during gonadotropi-releasing hormone agonist treatment. Gynecol Obstet Invest. 1992;34:102-104.

44. Marais C. Place de l'Agreal dans le traitment de la menopause. Rev Fr Gynecol Obstet. 1985;80:156-162.

45. Verbeke K, Dhont M, Vandekerchhove. Clinical and hormonal effects of long-term veralipride treatment on postmenopausal women. Maturitas. 1988; 10:225-230
46. Masmoudi K, Gras-Champel V, Lemaire-Hurtel AS, et al. Troubles extrapyramidaux sous veralipride (Agreal), traitement symptomatique des bouffees de chaleur: a propos de 17 cas. Rev Med Interne. 2005;26: 453-457.

47. Montemurro D, Rossi GP. Veralipride-induced acute coronary syndrome unmasking a non-secreting pheocromocytoma. J Endocrinol Invest. 2006;29:650-652.

48. Kunhardt-Rasch J, Rodríguez C, Contreras-Chávez J, Rio de la Loza Cava F, Karchmer S. Eficacia y seguridad del veralipride contra placebo en el tratamiento del síndrome climatérico. Perinatol Reprod Hum. 1991;5:21-27.

49. Raja M, Azzoni A. Tardive dyskinesia after long-term veralipride treatment. J Neuropsychiatry Clin Neurosci. 2005;17:252-253.

50. Sinning OM, Miranda M, Contreras SA. Trastornos del movimiento inducidos por trazodona y veralipride: casos clínicos. Rev Chil NeuroPsiquiat. 2005;43;133-136.

51. Teive HAG, Sa DS. Worsening of parkinsonism after the use of veralipride for treatment of menopause. Case report. Arq Neuropsiquiatr. 2001; $59 ; 123-124$.

52. Informe de farmacovigilancia, Laboratorios Carnot AF. 2009 Dec 3.

53. Rapkin AJ. Vasomotor symptoms in menopause: physiologic condition and central nervous system approaches to treatment. Am J Obstet Gynecol. 2007;196:97-106.
Clinical Interventions in Aging

\section{Publish your work in this journal}

Clinical Interventions in Aging is an international, peer-reviewed journal focusing on evidence-based reports on the value or lack thereof of treatments intended to prevent or delay the onset of maladaptive correlates of aging in human beings. This journal is indexed on PubMed Central, MedLine, the American Chemical Society's 'Chemical Abstracts Ser-

\section{Dovepress}

vice' (CAS), Scopus and the Elsevier Bibliographic databases. The manuscript management system is completely online and includes a very quick and fair peer-review system, which is all easy to use. Visit http://www.dovepress.com/testimonials.php to read real quotes from published authors. 